\title{
The effect of physical education and sports program on the positive growth and coping strategies of the adolescent with mental retardation
}

\author{
Huseyin Kirimoglu ${ }^{1 a}$, Gulsen Filazoglu Cokluk², Levent İlhan ${ }^{3}$ and Aysegül Öz ${ }^{1}$ \\ ${ }^{1}$ Sttkı Koçman University,Faculty of Sport Sciences, Muğla, Turkey \\ ${ }^{2}$ Zirveye İlkadım Special Education and Rehabilitation Center, Hatay, Turkey \\ ${ }^{3}$ Gazi University, School of Physical Education And Sports, Ankara, Turkey \\ ${ }^{4}$ Mustafa Kemal University, Department of Special Education, Hatay, Turkey
}

\begin{abstract}
This study explored the effect of a 10-week research-based Special Physical Education Program and sports activities on the positive growth and coping strategies of the children with mental retardation. The research group was consisted of 145 children aged between 11 and 13 whose diagnosis were "mental retardation". As a result, it was found out that -compared to the control group- there was an increased difference in the general scores and scores of the all subscales of the positive growth of the adolescent who were in the practice group and did physical education and sports activities regularly. The differences between the groups were significant $(\mathrm{P}<0.05)$. Children with special needs do perceive positive change. Sports activities and pysical education was related to the perception of change in positive way.
\end{abstract}

Keywords: Special needs; Positive growth; Coping

\section{Introduction}

Several psychological variables have been found to be associated with emotional adjustment and positive outcomes with impact in disability end chronic illness, $[15,23,7]$. A social factor that may predict perceived positives outcomes is the perceived availability of emotional support [22] social support in general has evidence positive relations with benefit finding or correlational studies of women with multiple sclerosis [18] and individual experiencing a variety of stressful events [19]. There is also broad theoretical and empirical

\footnotetext{
a Corresponding author: hkirim2005@gmail.com
} 
support for including coping in models of psychological growth [3, 22, 5, 24, 25]. Some studies shown that sports activities have positive impact like active coping, positive reframing, planning, and use of friends as social support seeking coping for emotional support acon disabled people life [12]. Children with mental retardation face numerous difficulties in life. The most important of these difficulties is the fact that they are not known enough and the belief that nothing can be done for them [12].Particularly, that the individuals have a limited mental capacity may affect their quality of life in all aspects. Families with the children with mental retardation may prefer leading an isolated life style due to the humiliation in the face of negative behaviours and attitudes against their children; for example: they are not accepted by the social environment, they are mocked and they are pitied or rejected; which as a result affects the lives of both the family members and the children with mental retardation negatively $[6,26]$. Activity training programs organized in a purposeful and significant manner affect all parts of development of the children with mental retardation. Movement means sports, dance, exercises and exploratory movements. The experiences obtained with movements should be considered as a basic instrument for growth and development [14].

In many researches, the positive effects of sports can be observed not only among the children and adolescents with normal development but also among the individuals with mental retardation [4]. According to the some studies in literature, sports help the individuals with special needs develop physically, psychologically and socially and facilitate their integration into the society [21]. It has been proved that physical activities and sports affect numerous variables -such as self-perception, psychological adaptation, attention level, happiness level, motor growth, social skills, communicational skills and perceptional growth etc.-positively [2, 12]. In light of these explanations, the aim of the present research was to assess the effect of special physical education and sports activities done regularly on the positive growth of the adolescent with mental retardation.

\section{Methodology}

The research group was consisted of 145 adolescent aged between 11 and 13 whose diagnosis were "mental retardation" (according to the results of WISC-R tests and IQ between 50 and 70). The research was designed in pretest-posttest model with control group. The practice group was consisted of 88 adolescent ( 38 girls, 50 boys) while control group was composed of 57 adolescent ( 26 girls, 31 boys).

\subsection{Measures}

The ways of coping inventory: WCI was developed and later revised by Folkman and Lazarus (1985). It assesses the thoughts and behaviours that the person uses to manage the problem and regulate the emotional response to the problem. The Stress Related Growth Scale: SRGS was developed by Park, Cohen \&Murch [19] to assess stress-related growth. In development of the SRGS. SRGS designed to measure the extent of positive personal outcomes that result from experiencing negative life events/ this instrument has shown good reliability and validity [19]. Gunes [10] translated SRGS into Turkish.

\subsection{Procedure}

As the contents, a special physical education program consisting of warm-up exercises, functional exercises (individual, paired, group staffed, station-racecourses) and sports games (paired, types of helping each other, group competitions and games with rules) was 
applied to the practice group 2 days a week and 1 hour each day. The special physical education program was designed with the approval of and in collaboration with two different specialized academicians who have been specialized in "Physical Education for the Disabled People, Child Development and Special Education". The special physical education program lasted for 10 days. The children of the control group were exempted from the program. The data were collected at the beginning and at the end of the practice program as group based with the evaluations of the mothers of the children were compared. For the data analysis; SPSS 14.0 software program was used. Independent sample t test was used for the independent comparisons while "paired sample t test" was used for the dependent comparisons and the significance level was 0.05 .

\section{Results}

Table 1. Comparison of pre-test scores of practice group and control group and comparison of independent $t$ test scores

\begin{tabular}{|c|c|c|c|c|c|c|c|}
\hline & PRETEST & $\mathrm{N}$ & $X$ & $\mathrm{~S}$ & $\mathrm{Sd}$ & $\mathrm{t}$ & $\mathrm{p}$ \\
\hline \multirow{2}{*}{ Social Support } & Practice Group & 88 & 56.68 & 17.23 & \multirow{2}{*}{143} & \multirow{2}{*}{0.150} & \multirow{2}{*}{0.880} \\
\hline & Control Group & 57 & 57.13 & 18.23 & & & \\
\hline \multirow{2}{*}{ Optimistic } & Practice Group & 88 & 52.43 & 18.16 & \multirow{2}{*}{143} & \multirow{2}{*}{0.366} & \multirow{2}{*}{0.714} \\
\hline & Control Group & 57 & 51.32 & 17.27 & & & \\
\hline \multirow{2}{*}{ Problem Solving } & Practice Group & 88 & 57.92 & 20.32 & \multirow{2}{*}{143} & \multirow{2}{*}{0.511} & \multirow{2}{*}{0.609} \\
\hline & Control Group & 57 & 59.65 & 19.21 & & & \\
\hline \multirow{2}{*}{ Helplessnes } & Practice Group & 88 & 45.12 & 19.52 & \multirow{2}{*}{143} & \multirow{2}{*}{0.139} & \multirow{2}{*}{0.889} \\
\hline & Control Group & 57 & 45.6 & 21.28 & & & \\
\hline \multirow{2}{*}{ Religious Coping } & Practice Group & 88 & 52.71 & 16.68 & \multirow{2}{*}{143} & \multirow{2}{*}{0.410} & \multirow{2}{*}{0.682} \\
\hline & Control Group & 57 & 53.87 & 16.53 & & & \\
\hline \multirow{2}{*}{ Positive Growth } & Practice Group & 88 & 51.67 & 16.68 & \multirow{2}{*}{143} & \multirow{2}{*}{0.310} & \multirow{2}{*}{0.574} \\
\hline & Control Group & 57 & 54.01 & 16.53 & & & \\
\hline \multirow{2}{*}{ Inventory Total score } & Practice Group & 88 & 53.72 & 17,03 & \multirow{2}{*}{143} & \multirow{2}{*}{0.152} & \multirow{2}{*}{0.879} \\
\hline & Control Group & 57 & 54.16 & 16.86 & & & \\
\hline
\end{tabular}

As the result of pre-test administered to the practice group and control group and when their mean scores of the coping strategies and positive growth were examined; it was found out that control group had higher mean scores for "Social Support Coping", "Optimistic Coping", "Problem solving coping", "Helplessness Coping" and Inventory Total score compared to practice group. At the beginning of the research process when independent variable of the research " 10 week special physical education program" was not implemented; it was found out that mean scores of both groups were similar to each other in terms of parameters of coping strategies and positive growth. When the pre-test scores of the groups were compared, it was explored that there was not a significant difference between the groups in terms of all parameters according to the results of the "independent $t$ test" $(\mathrm{p}>0.05)$.

As the result of post-test administered to the practice group and control group and when their mean scores of the coping strategies were examined; it was found out that practice group obtained higher scores in "Social Support Coping", "Problem Soving Coping", "Positive Growth" and Inventory Total score compared to the control group. On the other hand, control group had higher scores in "Helplessness Coping" and "Religious Coping" than practice group. At the end of research; it is possible to suggest that mean scores of the children in the practice group increased positively compared to the control group after " 10 week special physical education program" was implemented. Although mean scores of the children in the practice group increased in all parameters of coping strategies and positive 
growth; there was not a significant difference between the groups in terms of all parameters according to the results of the "independent t test" with which mean post-test scores of the groups were compared $(\mathrm{p}>0.05)$.

Table 2. Comparison of post-test scores of practice group and control group and comparison of independent $t$ test scores

\begin{tabular}{|c|c|c|c|c|c|c|c|}
\hline & PRETEST & $\mathrm{N}$ & $\bar{X}$ & $\mathrm{~S}$ & $\mathrm{Sd}$ & $\mathrm{t}$ & $\mathrm{p}$ \\
\hline \multirow{2}{*}{ Social Support } & Practice Group & 88 & 60.22 & 17.69 & \multirow{2}{*}{143} & \multirow{2}{*}{0.622} & \multirow{2}{*}{0.534} \\
\hline & Control Group & 57 & 58.47 & 16.28 & & & \\
\hline \multirow{2}{*}{ Optimistic } & Practice Group & 88 & 54.29 & 18.87 & \multirow{2}{*}{143} & \multirow{2}{*}{1.387} & \multirow{2}{*}{0.167} \\
\hline & Control Group & 57 & 51.44 & 15.43 & & & \\
\hline \multirow{2}{*}{ Problem Solving } & Practice Group & 88 & 60.46 & 18.21 & \multirow{2}{*}{143} & \multirow{2}{*}{0.318} & \multirow{2}{*}{0.750} \\
\hline & Control Group & 57 & 60.37 & 17.51 & & & \\
\hline \multirow{2}{*}{ Helplessnes } & Practice Group & 88 & 47.17 & 17.76 & \multirow{2}{*}{143} & \multirow{2}{*}{0.132} & \multirow{2}{*}{0.894} \\
\hline & Control Group & 57 & 46,73 & 20.56 & & & \\
\hline \multirow{2}{*}{ Religious Coping } & Practice Group & 88 & 54.75 & 16.4 & \multirow{2}{*}{143} & \multirow{2}{*}{0.059} & \multirow{2}{*}{0.952} \\
\hline & Control Group & 57 & 54.92 & 17.2 & & & \\
\hline \multirow{2}{*}{ Positive Growth } & Practice Group & 88 & 63.40 & 16.68 & \multirow{2}{*}{143} & \multirow{2}{*}{0.622} & \multirow{2}{*}{0.853} \\
\hline & Control Group & 57 & 54.20 & 16.53 & & & \\
\hline \multirow{2}{*}{ Inventory Total score } & Practice Group & 88 & 56.09 & 17,03 & \multirow{2}{*}{143} & \multirow{2}{*}{0.182} & \multirow{2}{*}{0.855} \\
\hline & Control Group & 57 & 56.63 & 16.86 & & & \\
\hline
\end{tabular}

It was found out according to the findings of pre-test and post-test that the mean scores of the practice group increased in all dimensions of quality of life. According to the results of "dependent t test" with which the increase in the coping strategies and positive growth after "10 week special physical education program" was assessed, it was seen that there was a significant increase in "Social Support Coping" and Positive growth $(\mathrm{p}<0.05)$.

\begin{tabular}{|c|c|c|c|c|c|c|c|}
\hline & PRETEST & $\mathrm{N}$ & $X$ & $\mathrm{~S}$ & $\mathrm{Sd}$ & $\mathrm{t}$ & $\mathrm{p}$ \\
\hline \multirow{2}{*}{ Social Support } & Practice Group & 88 & 58.68 & 18.23 & \multirow{2}{*}{143} & \multirow[t]{2}{*}{2.036} & \multirow[t]{2}{*}{$0.052 *$} \\
\hline & Control Group & 57 & 61.14 & 16.69 & & & \\
\hline \multirow{2}{*}{ Optimistic } & Practice Group & 88 & 52.43 & 18.16 & \multirow{2}{*}{143} & \multirow[t]{2}{*}{0.954} & \multirow[t]{2}{*}{0.440} \\
\hline & Control Group & 57 & 54.59 & 16.87 & & & \\
\hline \multirow{2}{*}{ Problem Solving } & Practice Group & 88 & 57.92 & 20.32 & \multirow{2}{*}{143} & \multirow[t]{2}{*}{0.734} & \multirow[t]{2}{*}{0.483} \\
\hline & Control Group & 57 & 59.75 & 18.21 & & & \\
\hline \multirow{2}{*}{ Helplessnes } & Practice Group & 88 & 45.12 & 19.52 & \multirow{2}{*}{143} & \multirow[t]{2}{*}{0.910} & \multirow[t]{2}{*}{0.253} \\
\hline & Control Group & 57 & 47.47 & 18.76 & & & \\
\hline \multirow{2}{*}{ Religious Coping } & Practice Group & 88 & 52.71 & 16.68 & \multirow{2}{*}{143} & \multirow[t]{2}{*}{1.002} & \multirow[t]{2}{*}{0.317} \\
\hline & Control Group & 57 & 54.85 & 16.41 & & & \\
\hline \multirow{2}{*}{ Positive Growth } & Practice Group & 88 & 58.63 & 18.23 & \multirow{2}{*}{143} & \multirow{2}{*}{0.622} & \multirow{2}{*}{0.853} \\
\hline & Control Group & 57 & 62.12 & 16.52 & & & \\
\hline \multirow{2}{*}{ Inventory Total score } & Practice Group & 88 & 53.72 & 17,03 & \multirow{2}{*}{143} & \multirow{2}{*}{1.543} & \multirow{2}{*}{0.151} \\
\hline & Control Group & 57 & 56.93 & 17.43 & & & \\
\hline
\end{tabular}

\section{Discussion and Conclusion}

In this research which was conducted to learn the effect of physical education and sportive activities which are regularly done for the mentally retarded children upon the coping strategies and positive growth; "10 week special physical education program" was the independent variable whereas level of positive growth and coping strategies was dependent variable. Comparison of the mean scores of the pre-tests administered to the groups demonstrated that the levels of the groups were similar to each other before the research. It is thought that similarity of the groups is a classical outcome of the researches 
designed with pre-test and post-test and control group; which is regarded as important in the sense that the findings and the results of the research is being built on concrete basis. At the end of research; it is possible to suggest that mean scores of the children in the practice group increased positively compared to the control group after " 10 week special physical education program" was implemented. The current study reported that recreative activities played a key role in integration with the environment and the society, friendship and social acceptance among the disabled individuals. With the conclusion of the study. The length of 10 week program used may have been insufficient. It is necessary that sportive activities should be continued among the mentally retarded children so that the increase in the positive growth and coping strategies of the practice group of our research could be significant and continuous. The increase in all dimensions was thought to be resulting from "special physical education program". With the increase in "Social Support Coping" dimension of coping strategies of the mentally retarded children in the practice group after the program was implemented; parents may have observed a correlation between physical education and sports and physical growth more. Considering the effects of mentally disabled individuals' participation in sportive activities upon positive psychological, social and motor fields; it is suggested that studies should examine not only the connection between sports and sportive competitions but also between sports and recreation and thus, positive effects that will be gained among the adolescent with mental retardation thanks to physical education and sports at the special education institutions should not be ignored.

\section{References}

1. Bruce, E. Compas, Sarah, S. Jaser, Jennifer, P. Dunbar, Kelly, H. Watson, Alexandra, H. Bettis, Meredith, A. Gruhn Ellen K. Williams, Coping and emotion regulation from childhood to early adulthood: Points of convergence. Aust. Journal Psychology Jun, 1; 66(2), 71-81, (2014).

2. Baron, L.J., Faubert C., The role of Tai Chi Chuan in reducing state anxiety and enhancing mood of children with special needs. Journal of Bodywork and Movement Therapies. 9(2), 120-133, (2005).

3. Bellizzi, K.M., Blank, T.O., Predicting Posttraumatic Growth in Breast Cancer Survivors, Health Psychology Vol(25) pp 47-56, (2006).

4. Carmeli, E., Zinger-Vaknin, T., Morad, M., Merrick, J., Can physical training have an effect on well-being in adults with mild intellectual disability? Mechanizm of Ageing Development, 126(2), 299-304, (2005).

5. Carver, C. S., Pozo, C., Harris, S. D., Noriega, V., Scheier, M. F., Robinson, D. S., et al., How coping mediates the effect of optimism on distress: A study of women with early stage breast cancer. Journal of Personality and Social Psychology, 65, 375-390, (1993).

6. Chou, Y.C., Schalock, R.L., Tzou, P.Y. Lin, L.C., Chang, A.L., Lee, W.P., Chang, S.C. Quality of life of adults with intellectual disabilities who live with families in Taiwan. J Intellect Disabil Res, 51(11), 875-83, (2007).

7. Filazoglu G, Griva K., Coping and social support and health related quality of life in women with breast cancer in Turkey. Psychol Health Med, 13(5), 559-73, (2008).

8. Friedman. L. C., Baer, P.E., Le wy, A., Lane, M., et al., predictors of psychological adjustment to breast cancer. Journal of Psychosocial Oncology, 6, 75-94, (1988).

9. Folkman, S., \& Lazarus, R.S., If it changes it must be process: Study of the emotion and coping during three stages of a college examination. Journal of Personality and Social Psychology, 48, 150-170, (1985). 
10. Gunes, H., Gender differences in distress, coping strategies, stress-related growth and factors associated with psychological distress and perceived growth following 1999, Marmara eartquake. Turk Psikoloji Dergisi, 42, 15-75, (2001).

11. Hilton, B., The relationship of uncertainty, control, commitment, and threat of recurrence to coping strategies used by women diagnosed with breast cancer. Journal of Behavioural Medicine, 41, 209-218, (1989).

12. İlhan, L., Eğitilebilir zihinsel engelli çocuklarda beden eğitimi ve spor aktivitelerinin ruhsal uyum düzeylerine etkisi, Doktora Tezi, Gazi Üniversitesi, Eğitim Bilimleri Enstitüsü, Ankara, (2007).

13. İlhan, L., Eğitilebilir Zihinsel Engelli Çocuklarda Beden Eğitimi ve Sporun Sosyalleşme Düzeylerine Etkisi. Kastamonu Eğitim Dergisi. 16(1), 315-324, (2008).

14. Kınalı, G., Zihin Engellilerde Beden - Resim - Müzik Eğitimi. Farklı Gelişen Çocuklar. (Ed: A. Kulaksızoğlu), Epsilon Yayınları, İstanbul, (2003).

15. Komblith, A. B., Hemdon, J.E., Zuckenman, E., Social support as a buffer to the psychological impact of stressful life events in women with breast cancer. Cancer, 91(2), 443-454, (2001).

16. İlhan L., Kırımoglu, H., Cokluk, F.G., Zihinsel Engelli Çocuklarda Düzenli Olarak yapılan beden eğitimi spor aktivitelerinin yaşam kalitelerine etkisi. Journal of Physical Education and sport science, 7, (2013).

17. Mcmohan, D.J., Social acceptance of children with developmental handicaps in integrated daycamps. University of Toronto (Canada), (1998).

18. Mohr, D.C., Dick, L.P., Russo, D., Pinn, J., Boudewyn , A. C., Likosky, W., \& Goodkin, D.E., The psychological impact of multiple sclerosis: Exploring the patient's perspective. Health Psychology, 18, 376-382, (1999).

19. Park,C.L., Cohen,L., Murch, R., Assessment and prediction of stress- related growth. Journal of Personality, 64, 71-105., (1996).

20. Park, C.L., Edmondson, D., Blank, T., Religious and Non-Religious Pathways to Stress-Related Growth in Cancer Survivors. Applied Psychology: Health and WellBeing. Published Online: Mar 9, 2009, (2009).

21. Savucu, Y., Biçer S.Y., Zihinsel engellilerde fiziksel aktivitelerin önemi. Türkiye Klinikleri Journal of Sport Science, 1(2), 117-122, (2009).

22. Sears, S., Stanton, A., Danoff-Burg, S., The yellow brick road and the emerald city: benefit finding, positive reappraisal coping, and posttraumatic growth in women with early-stage breast cancer. Health Psychology, 22(5), 487-497, (2003).

23. Segrin, C., Badger, T. A., Meek, P., Lopez, A. M., Bonham, E., \& Sieger, A., Dyadic interdependence on affect and quality of life trajectories among women with breast cancer and their partnres. Journel of Social and Personel Relationships, 22, 673-689, (2005).

24. Stanton, A. L., \& Snider, P.R., Coping with a breast cancer diagnosis: A perspective study. Health Psychology. 12, 16-23, (1993).

25. Tedeschi, R.G. Calhoun, L.G., The posttraumatic growth inventory: measuring the positive legacy of trauma. Journal of Traumatic Stress, 9, 455-471, (1996).

26. Yee Lim, M.S., Wong, C.P., Impact of cerebral palsy on the quality of life in patients and their families. Neurology Asia, 14, 27-33, (2009). 